\begin{tabular}{lll} 
KULTURA & $\begin{array}{l}\text { POLSKA A KADEMIA NAUK } \\
\text { KOMITET SOCJOLOGI }\end{array}$ \\
I & $\begin{array}{l}\text { INSTYTUT STUDIÓW POLITYCZNYCH } \\
\text { SPOLECLENSTMO nr } 4 \quad \text { DYNAMICS OF WORK AND LIFE CHANGES }\end{array}$ \\
\hline
\end{tabular}

KAMILA BIAEY

Institute of Sociology, University of Łódź

\title{
A SOCIOLOGICAL EXPLORATION IN THE SELF/WORLD RELATION
}

Review of: Hartmut Rosa (2016), Resonanz. Eine Soziologie der Weltbeziehung. Berlin: Suhrkamp.

Having been socialized into the critical theory tradition, Hartmut Rosa, professor of sociology and political science at the Friedrich-Schiller-Universität Jena, remains loyal to the well-established convention of understanding capitalist modernity as a wrong mode of existence. Nevertheless, his new book Resonanz. Eine Soziologie der Weltbeziehung [Resonance: A Sociology of the Relationship to the World] offers a new theoretical foundation, which focuses on the concepts of "resonance" and "the self/world relation" (Weltbeziehung).

The ground for this new epistemological approach had already been laid in his earlier books. In Beschleunigung: Die Veränderung der Zeitstrukturen in der Moderne (Social Acceleration: A New Theory of Modernity) and in Beschleunigung und Entfremdung (Acceleration and Alienation) he argues that a modern capitalist society can only stabilize itself dynamically. It systematically requires growth, acceleration and increase of innovation in order to reproduce its structural status quo. Although the dynamics mainly come through temporality, speed is not a problem per se. It is only a problem when it leads to different forms of alienation. The question remains, therefore, where the motivational energy comes from to keep enough growth, acceleration and innovation on an individual level?

The concept of resonance in this respect is a modification and extension of Axel Honneth's concept of recognition. Like his Doktorvater or Charles Taylor 
(whose political philosophy was at the core of Rosa's dissertation thesis), the author of Resonanz seeks to combine social analysis and political philosophy with an interest in subject formation. Last but not least, he is inspired by Taylor's phenomenological approach to social life, deriving mainly from Merleau-Ponty. For Rosa, resonance is the very process through which we are formed as subjects and through which the world we encounter and experience is constituted.

The reviewed book consists of an introduction, four main parts and in place of an epilogue, the author's response to the criticism of "resonance theory."

In the Introduction, Hartmut Rosa discusses his theory of the self/world relation derived from phenomenology, as well as its links to sociology, social theory and modernity. It is based on a strong phenomenological statement that basic experience is prior to the subject/object split: "something is present" (Merleau-Ponty 1965), and this presence is an embodied, aesthetic experience. As in Taylor's writings there is no subject/object dualism, instead, priority is given to the in-between, the constitutive interpretation. At this point and later in the book, Rosa refers to the inspiration he drew from an abundance of various sources-from mirror neuron research, through Peter Sloterdijk's (1998) depiction of the symbiotic relationship between a mother and her baby, to Bruno Latour and his recent book on modes of existence (2013). The latter, Rosa points out, articulates views that are very similar to his own conception of religion, one that has nothing to do with a cognitive belief-structure. Instead, being religious means being in a mode of existence in which one feels essentially connected to something out there that has the power to transform us. Rosa takes a similar phenomenological approach: what is our way of experiencing the world and constructing worlds?

In the first part of the book ("Die Grundelemente menschlicher Weltbeziehungen"), the author introduces resonance and alienation as the main concepts of the self/world relation. The pretext for this discussion is when he argues that conceptions of justice are insufficient as normative concepts for the endeavor of critical theory. Even though he is convinced that the distribution of the means, products and profits of production in modern capitalist society is unjust, the main problem is that life is based on a wrong mode of relating to the world.

For Rosa, alienation is not the so-called "artists' critique" (Künstlerkritik: Benjamin, Adorno, Marcuse, Fromm) of capitalist society, which we can address once we have brought an end to all economic injustice. It is the other way round: the wrong mode of being is responsible for the possibility of exploitation and injustice. In critical theory as well as in other critical approaches there is well-established convention of interpreting modernity as problematic precisely due to its effect of alienation, dis-enchantment-silencing the world. However, the problem is that critical theory has so far failed to demonstrate sufficiently what a different way or mode of being in the world could look like. 
One suggested alternative mode of being is "authenticity"; this, however, Rosa claims, depends too much on identification, and ties communities and individuals to certain forms of life. Autonomy does not really work as "alienation's Other" either, for sometimes we are completely autonomous but totally alienated, and sometimes we lose control, we are overwhelmed and are not alienated at all. Resonance for that matter means becoming vulnerable and losing control. It is something that happens in the inter-space, between "actors" in Bruno Latour's sense, or it is "intra-action" as described by Karen Barads (2012).

Nevertheless, alienation is not the opposite of resonance. Rosa regards it as being in a dialectical relationship with resonance. For resonance is not consonance, it requires an active presence of something that is beyond our grasp, elusive, and in this sense remains alien. It therefore must involve difference and transformation, and has no reifying implications.

In this part of the book the author also ventures further into the intricacies of the self/world relationship, going beyond the cognitive aspect and concentrating on its various physiological and emotional aspects. When you are in resonance, when you feel that the thing you interact with is important, then it speaks to you, it touches and affects you. Therefore this is one side of a resonant relationship: you are touched, affected $(A f<f e c t i o n)$. On the other hand, however, you also have the capacity for experiencing self-efficacy ( $E \rightarrow$ motion). You reach out to the other side, too. You are non-alienated from your work, for example, or from people with whom you interact, when you manage to have a responsive, transformative, non-instrumental relationship with them, a resonant relationship. In other words, resonance is synonymous with basic entanglement in the world; it is the process through which self and the world are constituted and shaped. All human beings are "resonant beings"; Rosa says that we do not need to learn to resonate, even though we might unlearn it or lose our capacity for entering into resonant relationships.

In part two of the book ("Resonanzsphären und Resonanzachsen") three different axes or dimensions of resonance are distinguished. One is horizontal, or social resonance, i.e. resonance between human beings. We find it in relationships of love, in friendship, but also in our understanding of true democracy. The second dimension of resonance is material, or diagonal. This dimension contains resonant forms of a relationship with the world of objects and artifacts, such as work, for example. And finally, there is the vertical dimension of resonance, which is about our relationship with life, or the world, or the universe-existential resonance. Describing it, the author uses Karl Jaspers' term Das Umgreifende denoting that we always need to have a sense of how we relate to the world as a whole, as a totality.

Part three of the book ("Die Angst vor dem Verstummen der Welt") encapsulates the perception from critical theory as well as from other critical approaches of capitalist society, and modernity even beyond capitalism, that 
these are epochs operating in a way geared towards instrumental efficiency, a mode of silent, instrumental relationship with the world.

The author's contention is that a lot of modern literature and philosophy (Schopenhauer, Kierkegaard, Nietzsche) is the expression of the ultimate fear of modernity that the world will fall utterly silent. Samuel Beckett, Franz Kafka and other writers he analyzes in this part narrate a self-world-relationship in which all axes of resonance are silent and dead. Cognitively and rationally speaking, Rosa continues his argument: for us, who are living in modernity, the silence of the universe is inescapable, it appears to be dead, irresponsive matter. But people like Latour or Philippe Descola (2013) say that this is a very strange and historically unique way of looking at the world around us. It might be part of the problem of our current cultural predicament, and not just a simple truth.

Not knowing what the world really is, we can nonetheless scrutinize the ways in which we experience it and relate to it, even against our cognitive rational convictions. Through our enacted conception and perception of nature, through our conception of history, through our conception of art, we potentially redevelop axes of resonance with the world as a totality. Rosa suggests that there is clearly a strong social need for a thorough analysis and critique of modern society: for an approach capable of integrating political, psychological, philosophical and sociological perspectives into a powerful critique of what has gone wrong in our world.

In the fourth part ("Eine kritische Theorie der Weltbeziehung"), Rosa elaborates on the "Triple A Approach" to the world, constitutive of his understanding of modernity. We implicitly believe, he says, that a good life consists in making more of the world "available", "attainable" and "accessible." This counters what he calls, on a structural level, the mode of dynamic stabilizationthe need of modern societies for progressive growth, acceleration and innovation-as conditions for reproducing their social structure and maintaining the status quo. These realms change their character with time, though persist as fundamental pathologies built into the social fabric of modern society (Adorno, Marcuse). With this "structural" mode of dynamic stabilization, Rosa continues, there is a complementary mode of cultural orientation. As subjects, we try to bring the world within our horizon of control and calculability. As a result, self and world turn cold and indifferent. The alternative to the mode of dynamic stabilization is the mode of resonance. We need to replace this stance, geared towards control and calculation, with a new way of relating to the world based on listening and responding.

Hartmut Rosa associates the concept of resonance with those contemporary scholars representing different disciplines (philosophy: Lambert Wiesing; psychiatry and psychotherapy: Thomas Fuchs; neuroscience: Vittorio Gallese) who turn to phenomenology and claim that every human contact with the world contains both the component of meaning and of presence. In this sense, they all have a profound impact on their fields of analysis, embracing a specific epi- 
stemology that foregrounds the fundamental "relational" nature of humans. It is in and from relationship that the I and the world emerge as two poles (Husserl, quoted in Wiesing 2014: 73). There are three main characteristics of this relationship: the I and the world are co-original (in the sense that they emerge together), they are reciprocal (in the sense that there is no subject without the world and without a subject there is no world); and they are different (in the sense that they are not identical and they are each defined on the basis of their reciprocal otherness) (Wiesing, quoted in Francesetti 2016).

Reciprocity and difference are indeed at the core of Hartmut Rosa's thinking of resonance, being both a descriptive and a normative notion. Seeking a "holistic" social theory, Rosa also perceives resonance as the foundation of a "monistic" moral philosophy. Like Levinas, Rosa, seems not to be giving up individual autonomy, but trying to radicalize it, deepen it by calling into question the experience of heteronomy (Levinas 1961). You are non-alienated, the author of Resonanz says, when you listen $(A f<f e c t i o n)$ and respond $(E \rightarrow$ motion), when you manage to have a responsive, transformative, non-instrumental relationship to something that is beyond your grasp. This puts Rosa in line with thinkers who wish to go beyond the goal that is ultimate for many philosophers, from left to right, from Marx to Heidegger, namely some kind of concept of autonomy. This so-called "autonomy orthodoxy" is necessary in any ethics, yet not sufficient to the experience of affect, dependency, or connectedness that might begin to address the problem of motivation in moral and political life (Critchley 2007). Resonance cannot yet be enforced, guaranteed or controlled. The attempt, Rosa argues, to turn the world into a sphere of encompassing resonance would not only lead to totalitarian politics, it would destroy the possibility of hearing the voice of the Other, and thus discern one's own voice in the long run. Similarly, Simon Critchley in his Infinitely Demanding: Ethics of Commitment, Politics of Resistance (2007) claims that the demand has for the most part been a repressive demand; it is not a question of being liberated from it but an issue of how one can think about restructuring that demand and making it one's own.

The above mentioned argument against autonomy orthodoxy within contemporary philosophy seems related to Hartmut Rosa's critique of contemporary literature and philosophy, and their implied ultimate fear that with modernity the world will fall utterly silent. Indeed, the concept of resonance embodies a "hermeneutics of trust" (Ricœur, Gadamer) as opposed to a "hermeneutics of suspicion" (Ricœur). This latter tradition started by "the three great destroyers" (Marx, Nietzsche, and Freud) and involving interpreting, reading people's motives in search of their emancipation from power structures and practices, has in fact created a worldless subject. "[...] if the world is to be thought of as a product constituted by a subject, then this subject cannot himself be thought of as part of the world" (Wiesing 2014: 108). Rosa's concept of silencing the world (Das Weltverstummen) in philosophy may therefore be read in the light of 
a critique of interpretationism tendency present in contemporary philosophy (Wiesing 2014). It is considered by some rigorous critics not only a philosophical position but a cultural symptom, a symptomatic mind, when the world is treated as a text. "Having abandoned the ideal of reaching a naked, rock-bottom, unmediated God's-eye view of reality, we seem impelled to embrace the opposite position, that we see everything through an interpretive veil or from an interpretive angle" (Shusterman 1990: 181).

\section{REFERENCES}

Barad, Karen. 2012. Agentieller Realismus: Über die Bedeutung materiell-diskursiver Praktiken. Berlin: Suhrkamp.

Critchley, Simon. 2007. Infinitely Demanding: Ethics of Commitment, Politics of Resistance. London-New York: Verso.

Descola, Philippe. 2013. Beyond Nature and Culture. Chicago: University of Chicago Press.

Francesetti, Gianni. 2016. "You cry, I feel pain." The emerging, co-created self as the foundation of anthropology, psychopathology and psychotherapy in Gestalt Therapy. In: J.-M. Robine (ed.). Self: A Polyphony of Contemporary Gestalt Therapists. St Romain la Virvée: Editions L'Exprimerie.

Fuchs, Thomas. 2017. Ecology of the Brain: The Phenomenology and Biology of the Embodied Mind. Oxford: Oxford University Press.

Gallese, Vittorio. 2014. The Birth of Intersubjectivity: Psychodynamics, Neurobiology, and the Self. New York: W. W. Norton.

Latour, Bruno. 2013. An Inquiry Into Modes of Existence. Cambridge: Harvard University Press.

Lévinas, Emmanuel. 1961. Totalité et infini. Essai sur l'extériorité. The Hague-Boston: Martinus Nijhoff.

Merleau-Ponty, Maurice. 1965. Phenomenology of Perception. London: Routledge \& Kegan Paul.

Rosa, Hartmut. 2010. Alienation and Acceleration: Towards a Critical Theory of Late-Modern Temporality. Aarhus: Aarhus University Press.

Rosa, Hartmut. 2013. Social Acceleration: A New Theory of Modernity (New Directions in Critical Theory). New York: Columbia University Press.

Shusterman, Richard. 1990. "Beneath Interpretation: Against Hermeneutic Holism." The Monist 73(2).

Sloterdijk, Peter. 1998. Bubbles. Sphere I: Microspherology. Cambridge: The MIT Press.

Wiesing, Lambert. 2014. The Philosophy of Perception: Phenomenology and Image Theory. London: Bloomsbury. 